\title{
EMISSION CHARACTERISTICS OF JATROPHA-ETHANOL AND JATROPHA- DIMETHYL ETHER FUEL BLENDS ON A DI DIESEL ENGINE
}

\author{
M.Loganathan ${ }^{\mathrm{a} *}$, A. Anbarasu ${ }^{\mathrm{b}}$ and A.Velmurugan ${ }^{\mathrm{c}}$ \\ ${ }^{a}$ Associate professor, Department of Mechanical Engineering, Annamalai University, India \\ ${ }^{\mathrm{b}}$ Assistant professor, Department of Mechanical Engineering, RVS College of Engineering and Technology, \\ Dindigul, India \\ ${ }^{c}$ Assistant professor, Department of Mechanical Engineering, Annamalai University, India \\ *corresponding email: logu692002@ rediffmail.com
}

\begin{abstract}
In this study, Biodiesel-Dimethyl Ether (BDE) and Biodiesel Ethanol (BE) were tested in a 4-cylinder direct-injection diesel engine to investigate the performance and emission characteristics of the engine under five engine loads at the maximum torque. The engine speed was maintained at $1500 \mathrm{rpm}$. Here the jatropha oil is used as a non edible oil to produce the biodiesel. The ethanol and dimethyl ether is used as an additive to enhance the engine combustion. The BDE 5 (biodiesel 95\% and dimethyl ether 5\%), BDE 10 (biodiesel 90\% and dimethyl ether 10\%) BDE 15(biodiesel 85\% and dimethyl ether 15\%) BE5 (biodiesel $95 \%$ and ethanol 5\%), BE10 (biodiesel $90 \%$ and ethanol 10\%) and BE15 (biodiesel 85\% and ethanol 15\%) were tested in the engine. The results indicate that when compared with neat jatropha, the engine performance increased and emission level decreased with adding the ethanol and diethyl ether with methyl ester of jatropha oil. In comparison with neat jatropha, the BDE5 and BE15 blends have higher brake thermal efficiency (BTE) of 12\% and 13\% respectively. The experimental results showed that the CO, HC emission is decreased and NOx emission is increased for higher blends of additives. The brakes specific fuel consumption (BSFC) decreased for BDE5 and BE5 compared to other combination of fuel.
\end{abstract}

Key Words: Dimethyl Ether, Biodiesel, Ethanol, methyl ester of jatropha.

\section{INTRODUCTION}

The demand for energy around the world is increasing, specifically the demand for petroleum fuels. World energy consumption is expected to increase to $180,000 \mathrm{GWh} /$ year by 2020 [1]. Facing the increasing consumption of petroleum fuels and the increasingly stringent emission regulations, biofuels, such as ethanol and biodiesel, have been explored to reduce fuel consumption and engine emissions. Biodiesel is an alternative diesel fuel consisting of alkyl monoesters of fatty acids derived from vegetable oil or animal fats. Because of its reproducibility, nontoxicity, and sulfur-free property, a considerable amount of recent research has focused on the use of biodiesel on diesel engines. Furthermore, due to its similar physical properties to diesel fuel, there is no need to modify the engine when the engine is fueled with its blends [2,3]. In comparison with conventional diesel fuels, the fuelborne oxygen in biodiesel may promote more complete combustion and thus reduce particulate matter (PM), carbon monoxide (CO) and total hydrocarbons (THC) in compression ignition (CI) engine, while increase nitrogen oxides (NOx) [4]. According to a review on emission data for heavy duty engines published by EPA (Environmental Protection Agency of USA) [5], from diesel to B20 (20\% biodiesel by volume), CO, HC, and PM decreased by $13 \%, 20 \%$ and $20 \%$ respectively, while NOx emission increased by $4 \%$ on average. The same trends are obtained in the review paper published by Lapuerta et al. [6]. Thus, the higher NOx emission arising from the use of biodiesel might be considered as an obstacle of biodiesel application. However, there are also opposite trends of NOx emission in the literature. The results of Rakopoulos et al. [7] showed a slight decrease in NOx emission.

Ethanol, with a high oxygen content of $35 \%$, has been used in compression ignition engine as ethanoldiesel blends. Lapuerta et al. [8] studied the emissions of diesel-bioethanol blends in a diesel engine and concluded that the use of ethanol-diesel blends provided a significant reduction on PM emissions, with no substantial increase in other gaseous emissions (NOx,HC,CO). Ahmed [9] compared a $10 \%$ ethanol-diesel blend and a $15 \%$ ethanol-diesel blend with baseline diesel fuel when applied to a compression ignition engine. They found $27 \%$ and $41 \%$ reduction in PM respectively for $10 \%$ and $15 \%$ ethanol-diesel blends, while an increase of $4 \%$ and $5 \%$ in NOx respectively for $10 \%$ and $15 \%$ ethanol-diesel blends. Moreover, the use of ethanoldiesel blends has some disadvantages; for instance, an additive is required for ensuring good mixing of the two fuels and the blended fuel has poor lubricity. Biodiesel could be served as a good additive in stabilizing ethanol in diesel blends. Kwanchareon et al. [10] studied the solubility and emission characteristics of diesel-biodiesel-ethanol blends. They found that $\mathrm{CO}$ and $\mathrm{HC}$ reduced significantly at high engine load, whereas NOx increased, when 
compared with those of diesel fuel. Chen et al. [11] reported that increasing ethanol in ester- ethanoldiesel blended fuel, the dry soot emission in PM was reduced significantly, the sulfate emission hardly changed, and the SOF emission in pm decreased when the ethanol percentage was less than $20 \%$. however, biodiesel and ethanol can be mixed without phase separation while the potential of the ethanol in reducing NOx emission is an added advantage. Ren et al. [12] and hansen et al. [13] showed that the drop in combustion temperature due to the higher heat of evaporation could suppress NOx emissions and concluded that ethanol could act as an effective NOx emissions reducing additive. There are limited literatures focused on the application of ethanolbiodiesel blends to diesel engine. Kumar et al. [14] applied ethanol in animal fat to a diesel engine. They found that NOx emission decreased, while $\mathrm{HC}$ and $\mathrm{CO}$ emissions increased at low loads but decreased at high loads. Lebedevas et al. [15] reported that $\mathrm{CO}$ and NOx emissions decreased from $10 \%$ to $12 \%$ for every $10 \%$ increase of ethanol blended with rapeseed oil methyl esters. Bhale et al. [16] studied the performance and emissions on Mahua biodiesel blended with ethanol. In their study, they found reduction of $\mathrm{CO}$ and $\mathrm{NO}$ emissions using $20 \%$ blended fuel but an increase in $\mathrm{HC}$ emission. However, there is lack of detailed data on performance and emission of ethanol and dimethyl ether additive with neat biodiesel (B100) produced from jatropha oil. Thus, the aim of this study is to investigate the performance and emissions of a diesel engine operating on ethanol- biodiesel and dimethyl ether- biodiesel blends, using biodiesel produced from jatropha oil, and to compare these results with.those obtained from neat biodiesel.

\section{PRODUCTION OF BIODIESEL}

Researchers have proved that oils and fats can be converted in to biodiesel by transesterification process [17-19]. Biodiesel is an alternative fuel, which has a correlation with sustainable development, energy conservation and environmental preservation. Biodiesel is biodegradable, non-toxic and essentially free from sulphur. In this work the Methyl ester of jatropha oil is produced by the Transesterification process. Esterification of jatropha oil is composed of heating of oil, addition of $\mathrm{KOH}$ and methyl alcohol, stirring of mixture, separation of glycerol, washing with distilled water and heating for removal of water. This process produces uniform quality of the alkyl esters and reduces viscosity and increases cetane number. In a transesterification reaction, the following parameters should be taken into account: water in the reagents, molar ratio of reagents, concentration of free fatty acids in oils, temperature, the reaction time, types of alcohol, and types of catalysts.In this research work the ethanol and dimethyl ether is used with biodiesel of jatropha oil. They are mixed and stirred in the magnetic stirrer for proper mixing. This mixture was kept under investigation for more than 24 hours to see the separation of fuels. It was confirmed that there is no separation of ethanol and biodiesel taking place. The ethanol is blended with the biodiesel in the proportion of $5 \%, 10 \%$ and $15 \%$ by volume which is called as BE5, BE10 and BE15. Similarly the dimethyl ether is blended with the biodiesel in the proportion of $5 \%, 10 \%$ and $15 \%$ by volume which is called as BDE5, BDE10 and BDE15. The addition of ethanol to biodiesel changes the physicochemical properties of the blends. By using ethanol, density, kinematic viscosity, low calorific value and aromatics fractions of the blends decrease. Simultaneously, H/C ratio and oxygen content of the blends are enhanced, which has some favorable effects on the ignition and combustion of the blends. The main purpose of blending ethanol with biodiesel, as a solvent additive, is to research the possibility to use blended fuels with high percentages of biodiesel an unmodified diesel engine.

\section{TEST ENGINE AND FUEL PROPERTIES}

The experiments were carried out on a naturally aspirated, water-cooled, 4-cylinder, direct-injection diesel engine. The specifications of the engine are shown in Table 1 . The major properties of the fuels are shown in Table 2.

\section{Table 1 . Engine specifications}

\begin{tabular}{lll}
\hline Type & $:$ & $\begin{array}{l}\text { Vertical, } \\
\text { cooled, Four stroke }\end{array}$ \\
\hline Make & $:$ & KIRLOSKAR AV-1 \\
\hline Number of cylinder & $:$ & One \\
\hline Bore & $:$ & $87.5 \mathrm{~mm}$ \\
\hline Stroke & $:$ & $110 \mathrm{~mm}$ \\
\hline $\begin{array}{l}\text { Displacement } \\
\text { Volume }\end{array}$ & $:$ & $661 \mathrm{CC}$ \\
\hline Compression ratio & $:$ & $17.5: 1$ \\
\hline Maximum power & $:$ & $3.7 \mathrm{~kW}$ \\
\hline $\begin{array}{l}\text { Speed } \\
\text { Dynamometer }\end{array}$ & $:$ & $\begin{array}{l}\text { Eddy current } \\
\text { dynamometer }\end{array}$ \\
\hline $\begin{array}{l}\text { Injection opening } \\
\text { angle }\end{array}$ & $:$ & $23 \mathrm{~b}$ TDC \\
\hline $\begin{array}{l}\text { Injector opening } \\
\text { pressure }\end{array}$ & $:$ & $20 \mathrm{Mpa}$ \\
\hline
\end{tabular}


Table 2. Fuel properties

\begin{tabular}{|c|c|c|c|c|}
\hline Properties & Diesel & $\begin{array}{c}\text { Methyl } \\
\text { ester of } \\
\text { Jatropha } \\
\text { oil }\end{array}$ & Ethanol & $\begin{array}{c}\text { Dimethyl } \\
\text { Ether }\end{array}$ \\
\hline $\begin{array}{c}\text { Density at } \\
\text { (g/cc) }\end{array}$ & $\begin{array}{c}0.8 / 0 . \\
84\end{array}$ & 0.880 & 0.789 & 0.197 \\
\hline $\begin{array}{c}\text { Kinematic } \\
\text { Viscosity } \\
\text { @ } 40 \text { C } \\
\text { (cSt) }\end{array}$ & $\begin{array}{c}2.0 \text { to } \\
4.5\end{array}$ & 4.36 & 1.52 & 1.84 \\
\hline $\begin{array}{c}\text { Calorific } \\
\text { value } \\
\text { (kJ/kg) }\end{array}$ & $\begin{array}{c}4200 \\
0\end{array}$ & 41000 & 28000 & 28882 \\
\hline $\begin{array}{c}\text { Flash Point } \\
(\mathrm{C})\end{array}$ & 80 & 138 & 16 & -41 \\
\hline $\begin{array}{c}\text { Fire Point } \\
(\mathrm{C})\end{array}$ & 86 & 136 & 362 & 13 \\
\hline $\begin{array}{c}\text { Ash content } \\
(\%)\end{array}$ & $\begin{array}{c}0.01 \\
\text { to } 0.1\end{array}$ & 0.01 & -- & --- \\
\hline
\end{tabular}

In Table 2 the lower heating values of biodiesel were determined with bomb calorimeter. The densities of the three fuels were measured at $20^{\circ} \mathrm{C}$. Other properties of the fuels were obtained either from the literature or from fuel specifications.

\section{EXPERIMENTAL PROCEDURE}

The experimental setup is shown in Fig.1. The engine was connected to an eddy current dynamometer, and a control system was used for adjusting its speed and torque. The engine was run at a constant speed of $1500 \mathrm{rpm}$. The NOx, CO and HC emission were measured with non-dispersive infrared analyzers (NDIR) (Make: HORIBA make Gas Analyser). The gas analyzers were calibrated with standard gases and zero gas periodically. Experiments were conducted at the engine speed of $1500 \mathrm{rpm}$ and at five engine loads. At each engine operating mode, experiments were carried out for the biodiesel (B100), biodiesel ethanol mixture (BE) namely BE5, BE10, BE15 and biodiesel-dimethyl ether (BDE) namely BDE5, BDE10, BDE15 respectively. In this study, the diesel engine was not modified during all the tests. Before each test, the engine was allowed to operate with the new fuel for twenty minutes to clean the fuel system which is used in the previous running. The data were recorded continuously for $5 \mathrm{~min}$ to reduce experimental uncertainties, and average values were presented.

\section{RESULTS AND DISCUSSION}

The performance and emission characteristics for the various load conditions for different fuels are analyzed and the results are presented in the following sections.

\section{Brake Thermal Efficiency}

The variation of brake thermal efficiency (BTE) with respect to load for different additives proportion of ethanol and dimethyl ether with jatropha biodiesel were considered for the present analysis and presented in Fig.2. In all cases, brake thermal efficiency has the tendency to increase with increase in applied load. This is due to the reduction in heat loss and increase in power developed with increase in load. The thermal efficiency of all blends of biodiesel-dimethyl ether (BDE) and biodiesel ethanol (BE) is higher than that of neat jatropha oil (B100). This is due to better mixture formation as a result of high volatility, lower viscosity and lower density of BDE and BE blended fuels. The BTE of BDE5, BDE10, BDE15, BE5, BE10 and BE15 blends gives the higher efficiency compared to neat biodiesel .This is because of addition of more additives of dimethyl ether and ethanol decrease the viscosity of mixture and improve the atomization and hence better combustion takes place. It is observed from the figure that BTE of BDE5, BDE10, and BDE 15 is $12 \%, 7 \%$, and $4 \%$ higher than that of neat jatropha at full load $(3.7 \mathrm{~kW})$. Similarly the BTE of BE5, BE10 and BE15 are 7\%, $9 \%$ and $13 \%$ higher than the neat biodiesel at full load.

\section{Brake Specific Fuel Consumption}

The variation of brake specific fuel consumption (BSFC) with load for different fuels is presented in Fig.3. For all fuels tested, BSFC is found to decrease with increase in the load. Increased BSFC is found with all BDE blends are due to the faster burning rates and more heat release rate ${ }^{20}$. The BSFC of jatropha dimethyl ether and ethanol blends are higher than that of neat biodiesel for all loads. This is proved from the graph that the BDE and BE blend gives more fuel consumption compared to neat jatropha oil (B100). BSFC for BDE5, BDE10 and BDE15 are $19 \%, 21.2 \%$ and $25 \%$ higher than that of neat jatropha. The increase of BSFC is mainly due to the lower calorific values of biodiesel and ethanol compared with that of neat jatropha. Beyond the certain percentage of additives namely BDE10 the BSFC increases due to the lower calorific value of total mixture. Hence, the specific fuel consumption of the higher percentage of blends increases as compared to that of neat biodiesel.

\section{Hydrocarbon Emission}

The variation of $\mathrm{HC}$ emissions are shown in Fig.4. Compared with neat jatropha oil, the BDE blends gives lower HC emissions. The higher oxygen content of biodiesel leads to better combustion, resulting in lower $\mathrm{HC}^{21}$. The $\mathrm{HC}$ emissions for jatropha oil are $34 \mathrm{ppm}$, while for BDE5, BDE10 and BDE15 are 19 ppm, 25ppm and 27 ppm respectively, at full load. The HC emissions of BDE15 decrease 
$20 \%$ at the maximum load $(3.7 \mathrm{~kW})$ of the engine in comparison with neat jatropha oil. The higher oxygen content in biodiesel and addition of diethyl ether results in lower $\mathrm{HC}$ emission for BDE5, BDE10 and BDE15. For BDE15, the amount of diethyl ether could increase the oxygen content and reduce the viscosity and density of the blended fuel, leading to improved spray and atomization, better combustion and hence lower $\mathrm{HC}$ emissions. The same trends are found for biodiesel ethanol (BE) blends.

\section{Carbon Monoxide Emission}

The Fig.5 shows that the $\mathrm{CO}$ emission of BDE5, BDE10 and BDE15 fuel is lower than that of neat jatropha oil at all loads. This is because of the higher oxygen content of biodiesel, which could improve the combustion process ${ }^{22}$. The $\mathrm{CO}$ emissions increase as the air fuel ratio becomes greater than the stoichiometric value. With increasing jatropha dimethyl ether and ethanol percentage, $\mathrm{CO}$ emission level increases. The reductions of $\mathrm{CO}$ for BDE5, BDE10 and BDE15 is $67 \%, 51 \%$ and $35 \%$ respectively at full load, compared to neat jatropha oil. This can be explained by the enrichment of oxygen owing to the diethyl ether and biodiesel addition, in which an increase in the proportion of oxygen will promote the further oxidation of $\mathrm{CO}$ during the engine exhaust process.

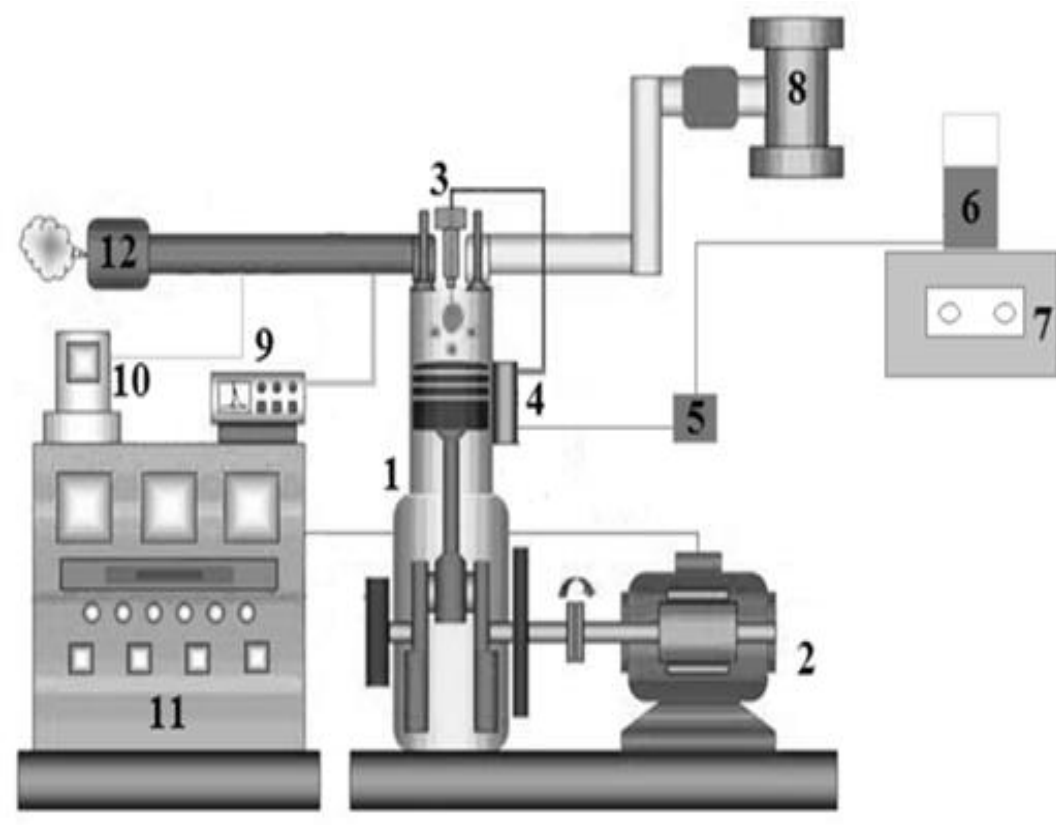

1. Kirloskar AV 1 Engine

2. Eddy current dynamometer

3. Injector

4. Fuel pump

5. Fuel filter

6. Fuel Tank

7. Weighing balance

8. Air stabilizing tank

9. HORIBA-gas analyzer

10. Smoke meter

11. Dynameter control

12. Exhaust pipe

Figure 1. Experimental Setup 


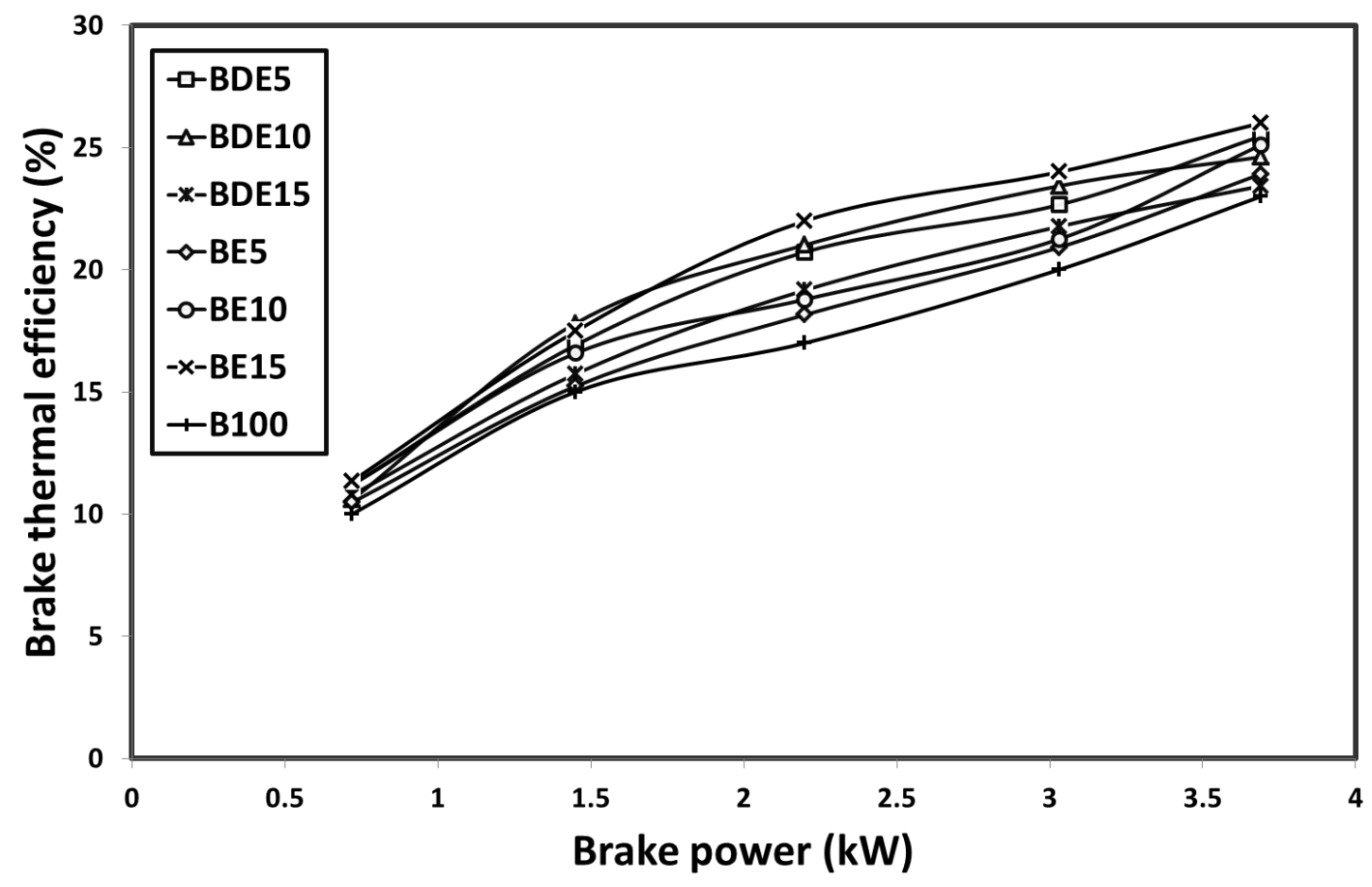

Figure 2. Comparison of Brake thermal efficiency.

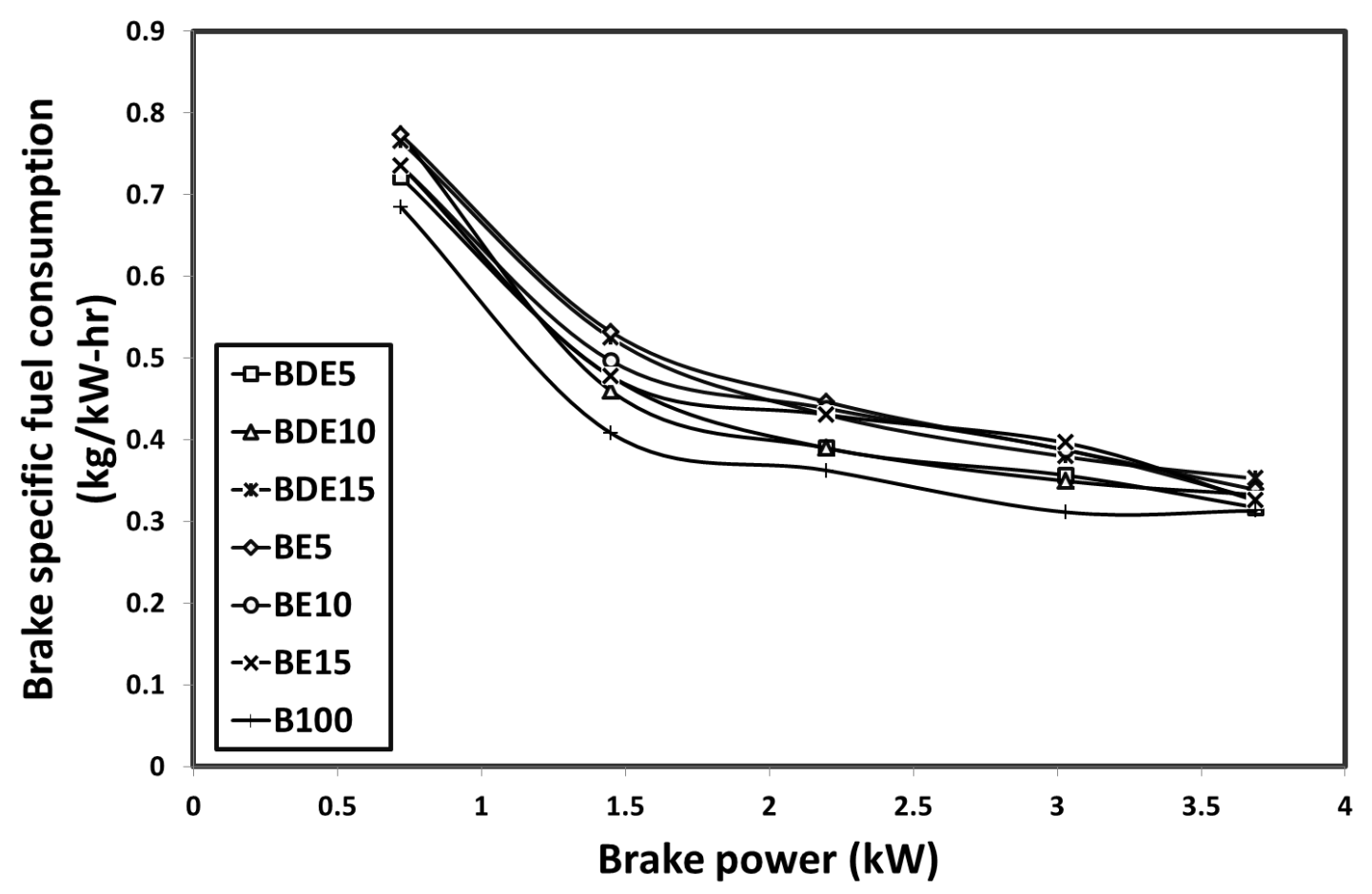

Figure 3. Comparison of brake specific fuel consumption. 


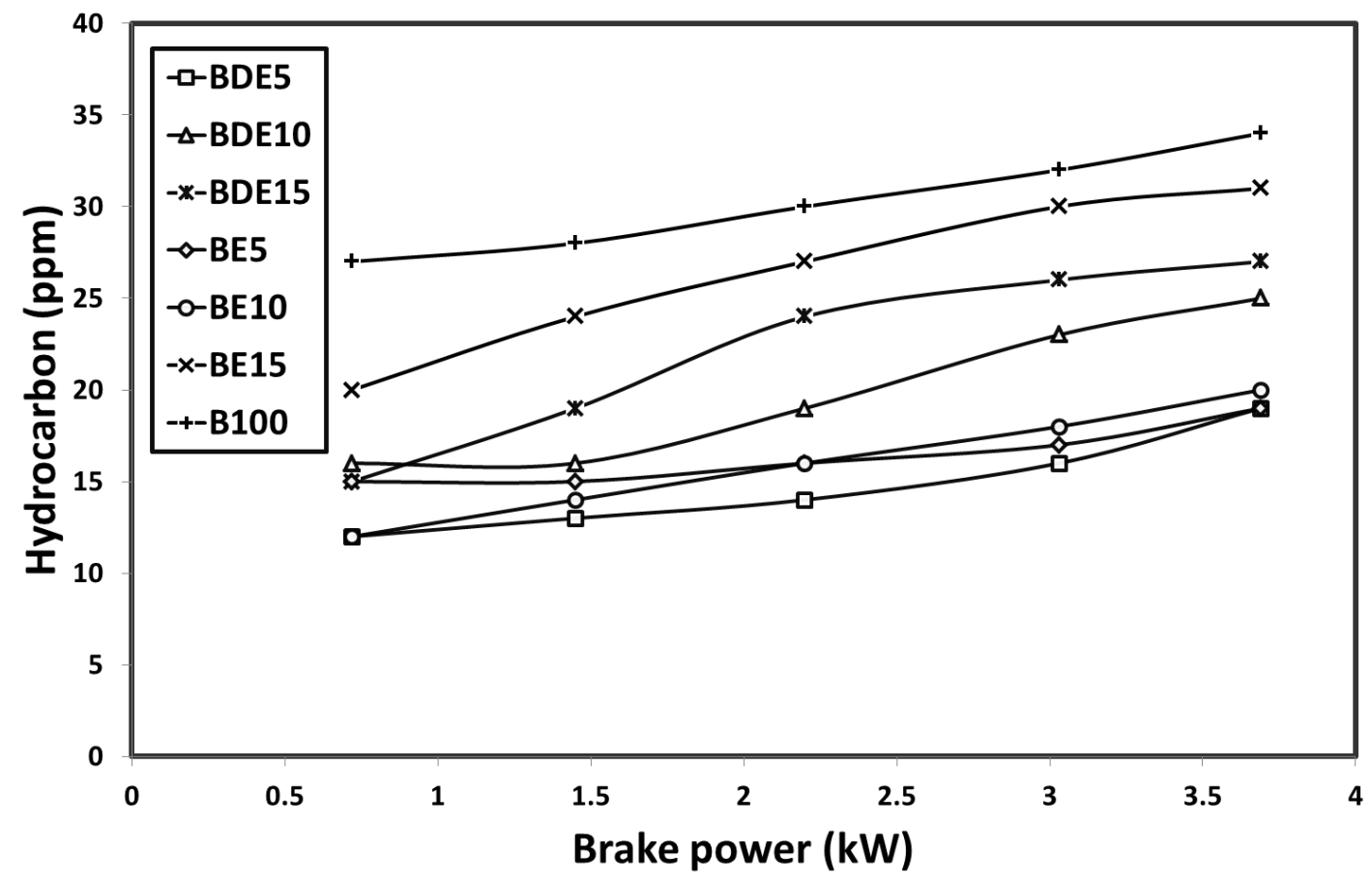

Figure 4. Comparison of $\mathrm{HC}$ emission.

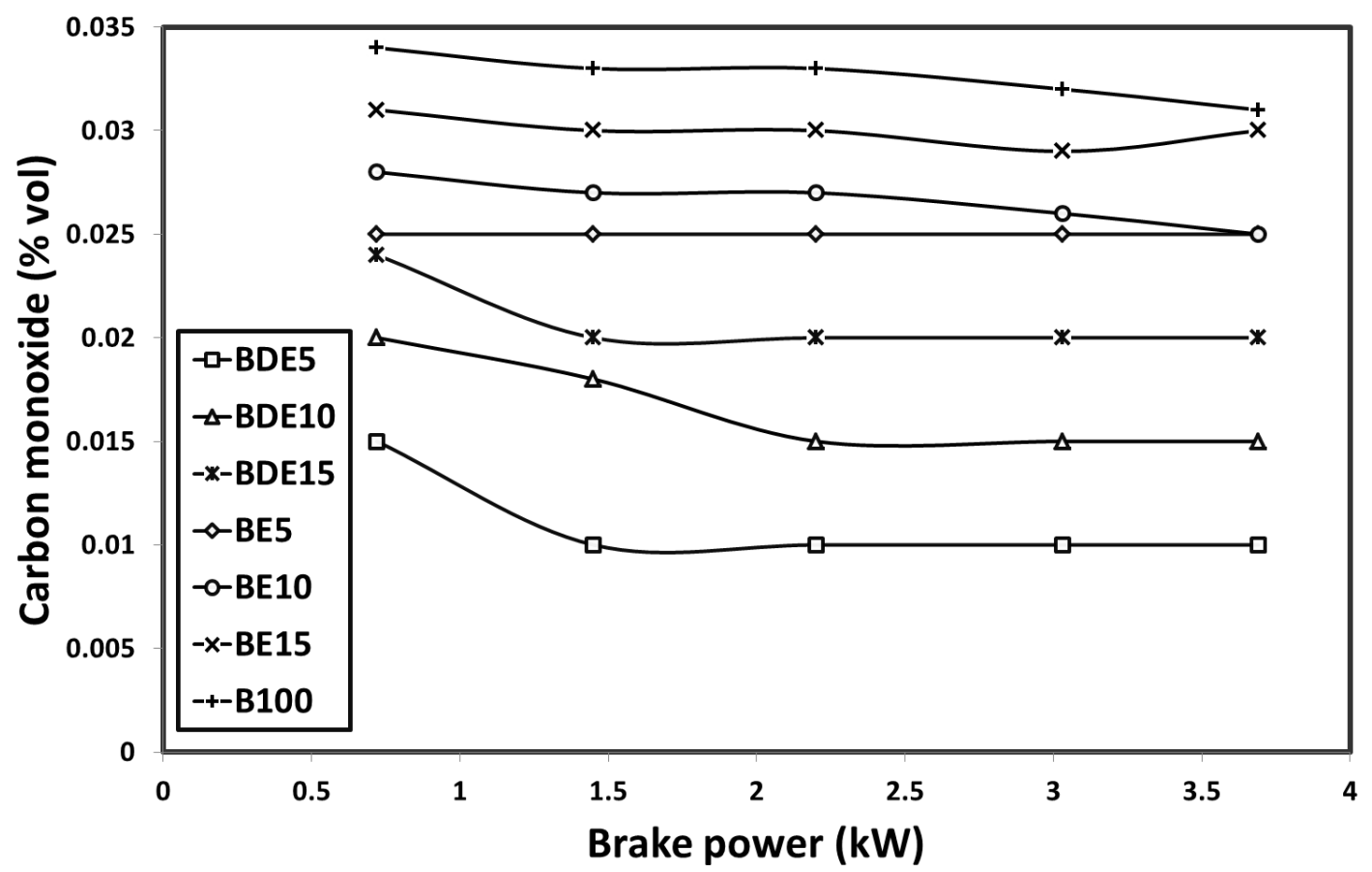

Figure 5. Comparison of $\mathrm{CO}$ emission. 


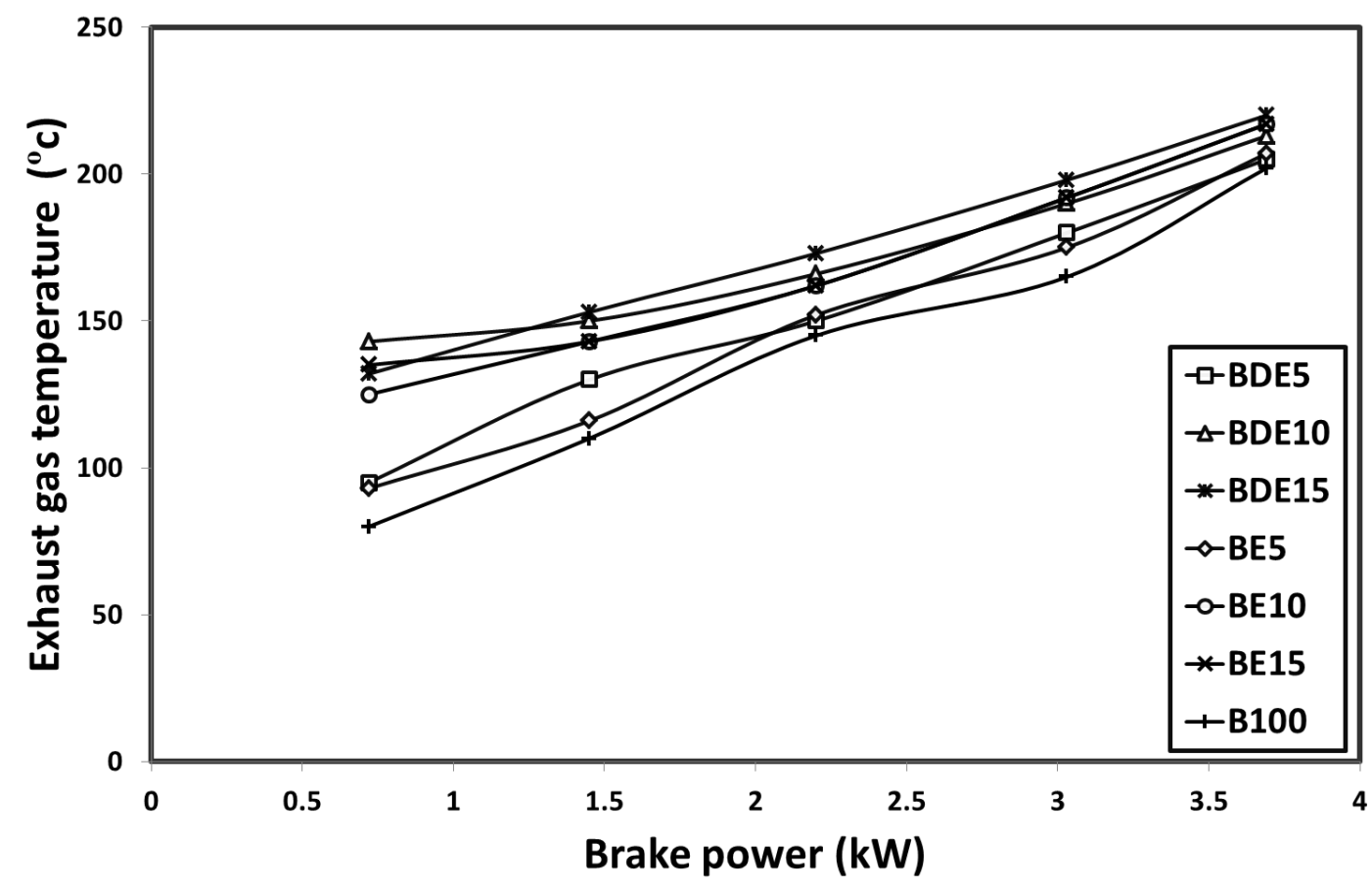

Figure 6. Comparison of exhaust gas temperature

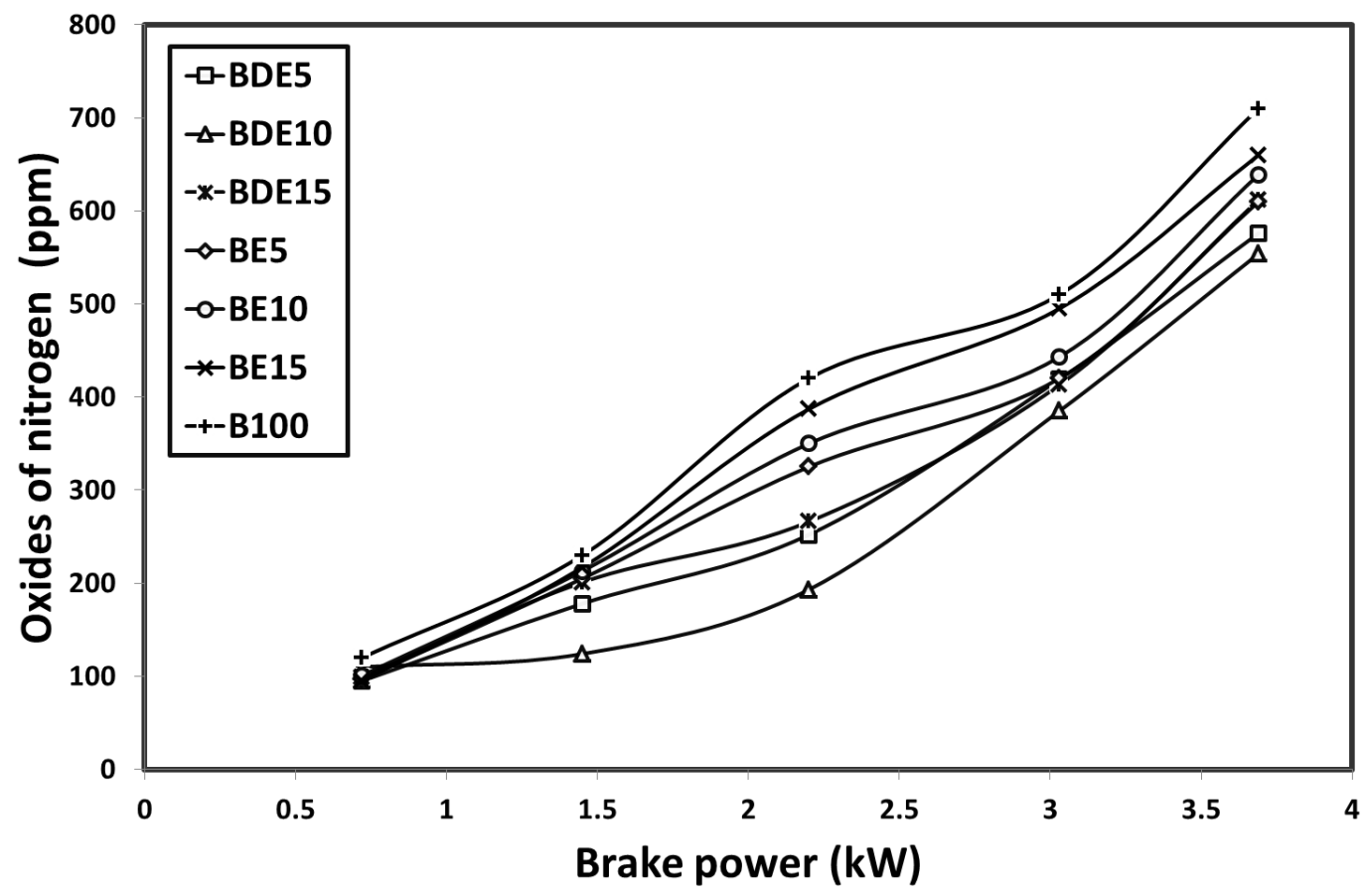

Figure 7 . Comparison of oxides of nitrogen 


\section{Exhaust Gas Temperature}

The exhaust gas temperatures were increased for all the fuels with the increase of applied load ${ }^{22}$. It is seen that the exhaust temperature of dimethyl ether and ethanol with biodiesel is increased because of enhanced combustion, compare to neat jatropha oil. In Fig. 6, BDE15 shows higher temperature distribution at each load test on the engine than the other fuels namely BDE5 and BDE10. The main reason for large difference between BDE15 and neat jatropha oil (B100), may be the improved combustion of BDE15, due addition of dimethyl ether with biodiesel. Another reason may be the shortened combustion period of BDE15 with increased flame velocity. The minimum exhaust gas temperature was obtained for neat jatropha oil.

\section{Oxides of Nitrogen Emission}

The NOx emissions are shown in Fig. 7. The NOx emissions increase with increase in the engine load. Compared with the neat jatropha oil, the NOx emissions for BDE15 decreased by $15 \%$ at full load. In addition, with increase of ethanol and dimethyl ether quantity with biodiesel, the NOx emission also increase. The thermal mechanism dominates the formation of NOx in biodiesel combustion ${ }^{1}$. Thus the major factors affecting NOx formation are combustion temperature, local oxygen concentration and residence time in the high temperature zone. For the BE blends, the cooling effect of ethanol associated with its lower calorific value and higher latent heat of evaporation could reduce the combustion temperature and hence reduce the NOx emissions. For the BE fuels, the cooling effect of ethanol seems to be the dominating effect leading to the overall reduction of NOx emission. The percentage of reduction of NOx for BDE5, BDE10 and BDE15 is 14\%, 10\%, and $7 \%$ at full load compare to neat jatropha oil.

\section{CONCLUSION}

Based on the experimental results the performance and emissions characteristics of diesel engine using $\mathrm{BDE}, \mathrm{BE}$ and neat jatropha oil have been analysed and presented as follows.

- The brake thermal efficiency is increased with blends of jatropha dimethyl ether and ethanol (BDE5, BDE10, BDE15, BE5, BE10 and BE15) compared to neat jatropha oil operation. The BTE of BDE5, BDE10, and BDE 15 was $12 \%, 7 \%$, and 4 $\%$ higher than that of neat jatropha at full load $(3.7 \mathrm{~kW})$. Similarly the BTE of $\mathrm{BE} 5, \mathrm{BE} 10$ and BE15 are $7 \%, 9 \%$ and $13 \%$ higher than the neat jatropha oil at full load.

- The Brake specific fuel consumption is increased in the case of jatropha dimethyl ether and ethanol compared to neat jatropha oil. Brake specific fuel consumption for BDE 5, BDE10 and BDE15 are $19.06 \%, 21.18 \%$ and $25 \%$ higher than that of neat jatropha oil.

- The CO and HC emissions were reduced with the use BDE and DE fuels, compared to neat jatropha oil for all load condition.

- The exhaust gas temperature was increased for BDE and BE fuels at all loads compared to neat jatropha oil.

- The NOx emission was decreased with addition of ethanol and dimethyl ether. The percentage of reduction of NOx for BDE5, BDE10 and BDE15 is 14\%, 10\%, and $7 \%$ at full load compare to neat jatropha oil.

On the whole it was concluded that the jatropha -dimethyl ether and jatrophaethanol blends can be used as alternative fuels in diesel engine. The addition of additives with dimethyl ether and ethanol with jatropha biodiesel improved the engine performance and decreased the emission level.

\section{REFERENCES}

[1] Fernando,S.,C.Hall, and Jha, S., 2006, "NOx reduction from biodiesel fuels.," Energy Fuels, vol.20, pp.376-82.

[2] Ramadhas, AS., Jayaraj, S., and Muraleedharan, C., 2004, "Use of vegetable oils as I.C. engine fuels - A review," Renew Energy., vol .29, pp.72742.

[3] Graboski, M.S., and McCormick, R.L., 1998, "Combustion of fat and vegetable oil derived fuels in diesel engines," Prog Energy Combust Sci., vol .24 , pp.125-64.

[4] Zheng,M.,Mulenga,M.C., Reader,G.T.,Wang, M., Ting, D.S.K. and Tjong., J., 2008, "Biodiesel engine performance and emissions in low temperature combustion," Fuel.,vol. 87,pp.714-22.

[5] Environmental Protection Agency of USA.,2002, "A comprehensive analysis of biodiesel impacts on exhaust emissions," Draft tech. report., EPA420-P-02-001.

[6] Lapuerta, M., Armas, O., and RodriguezFernandez, J., 2008, "Effect of biodiesel fuels on diesel engine emissions," Prog Energy Combust Sci, vol. 34, pp.198-223.

[7] Rakopoulos , C.D., Antonopoulos, K..A., Rakopoulos , D.C., Hountalas , D.T., and Giakoumis, EG., 2006, "Comparative performance and emissions study of a direct injection diesel engine using blends of diesel fuel with vegetable oils or bio-diesels of various origins," Energy conversion management,vol.47, pp.3272-87. 
[8] Lapuerta,M., Armas,O., and Herreros Jose,M., 2008, "Emissions from a diesel-bioethanol blend in an automotive diesel engine," Fuel ,vol.1, pp.2531.

[9] Ahmed, I., 2001, “Oxygenated diesel:emissions and performance characteristics of ethanol- diesel blends in CI engines," SAE Tec Paper No. 200101-2475.

[10] Kwanchareon, P., Luengnaruemitchai, A., and Jai-In,S.,2007, "Solubility of a diesel- biodieselethanol blend, its fuel properties, and its emission characteristics from diesel engine," Fuel ,vol. 86, pp.1053-61.

[11] Chen, H., Shi-jin, S., and Jian-xin, W., 2007, "Study on combustion characteristics and pm emission of diesel engines using ester-ethanoldiesel blended fuels," Proc combust inst, vol. 31, pp. 2981-89.

[12] Ren, Y., Huang ,Z.H., Jiang ,D.M., Li ,W., Liu, B., and Wang,X.B., 2007, "Effect of the addition of ethanol and cetane number improver on the combustion and emission characteristics of a compression ignition engine," Proc Inst Mech Eng Part D -J Automob Eng, ”vol. 222, pp.1077-87.

[13] Hansen, AC., Gratton, MR., and Yuan ,W., 2006, "Diesel engine performance and NOx emissions from oxygenated biofuels and blends with diesel fuel. Trans Am soc agric biol engg," vol.49, pp.589-95.

[14] Kumar, M.S., Kerihuel,A., Bellettre,J., and Tazerout,M., 2006, "Ethanol animal fat emulsions as a diesel engine fuel - Part 2: Engine test analysis," Fuel, vol.85, pp.2646-52.

[15] Lebedevas, S., Lebedeva, G., Makareviciene, V., Janulis, P., Sendzikiene, E.,2009, "Usage of fuel mixtures containing ethanol and rapeseed oil methyl esters in a diesel engine," Energy fuels,vol.23, pp.217-23.
[16] Bhale, P.V., Deshpande,N.V., and Thombre, S.B., 2009, "Improving the low temperature properties of biodiesel fuel," Renew Energy, vol. 34, pp.794-800.

[17] Mustafa Ozcanli, Ali Keskin, and Kadir Aydın, 2011, "Biodiesel Production from Terebinth (Pistacia Terebinthus) Oil and its Usage in Diesel Engine, International

Journal of Green Energy, vol.8: 5, pp.518-528.

[18] Kabir, E., Hussain,D., Haque, A., and Kim,K.H., 2009, “ Prospects for Biodiesel Production from Jatropha Curcas: A Case Study of Bangladesh Agricultural University Farm, International Journal of Green Energy, vol.6: 4, pp.381-391.

[19] Satyanarayana, M., and Muraleedharan,C., 2010, "Methyl Ester Production from Rubber Seed oil Using Two-Step Pretreatment Process, International Journal of Green Energy, vol.7: 1, pp.84-90.

[20] Dung Nguyen, and Damon Honnery, 2008, "Combustion of bio-oil ethanol blends at elevated pressure, Fuel, vol. 87, pp.232-243.

[21] Sukumar Puhan, G. Nagarajan,N., Vedaraman, B.V., and Ramabramhmam, 2007, "Mahua Oil (Madhuca Indica Oil) Derivatives as a Renewable Fuel for Diesel Engine Systems in India- A Performance and Emissions Comparative Study," International Journal of Green Energy, vol.4: 1, pp.89-104.

[22] Srivastava. P.K., Madhumita Verma, 2008, "Methyl ester of karanja oil as alternative renewable source energy, Fuel, vol.87, pp.1673-77. 